\title{
On the so-called curative verbs in Finnish
}

0.1 . Abstract. This paper is concerned with the so-called curative verbs in Finnish, that is verbal derivatives denoting that the activity expressed by the basic verb is made to be carried out by someone other than the subject of the derived verb. In this article attention will be focused on the structure of these verbs, on their identity among the causatives, on the recursiveness of the derivative process and its parameters, as well as on the occurrence of curatives in some Finno-Ugric and other languages. The summary emphasizes the need for further study of the curative derivation both diachronically and synchronically, and the importance of curativity from the viewpoint of interdisciplinary linguistics, typology, language universals and the theory of word-formation.

0.2. I want to record my indebtedness to Professors Alho Alhoniemi, Aulis J. Joki, Alpo Räisänen, Paavo Siro and Antti Sovijärvi, for valuable advice and examples from languages of the Finno-Ugric family. For the conclusions presented below I alone am responsible.

1.1. When the troupe of actors came to Elsinore, Prince Hamlet conceived a plan: "I'll have these players/Play something like the murder of my father/Before mine uncle" (Haml. II.ii. 631-2). The construction he used to express his stratagem is a special kind of causative that is referred to by the term curative in Finnish grammar. The above quotation displays the basic structure of the curative causative: an initiator or indirect agent will cause the actants or direct agents to carry out a given activity (for terminology see Lyons 1969: 385 and Kytömäki 1979: 141). This is to say that the subject of the curative verb is different from the subject of the activity that is made to be carried out.

In English as well as most Indo-European languages spoken in Europe curative causativity is expressed by means of a construction similar to that used by Prince Hamlet ${ }^{1}$, also in Finnish but in that language there is also a synthetic curative, which is derived from the basic verb by means of a de- 
rivative affix. Such a verbal derivative expresses the fact that the activity denoted by the basic verb is caused to be performed by some one else than the subject of the derivative, as Vesikansa (1978: 113) demonstrates.

antaa tiivistää (= TIIVISTYTTĂ ikkunat "to have the windows draught-poofed"

seuran esimiehestä annettiin lyödä (= LYƠTETTIIN) mitali "They had a medal stamped of the president of the society"

1.2. In her valuable and detailed survey of the study of causative derivatives in Finnish, Kytömäki (1978: 129-150) poses the question of whether it is necessary to distinguish a special curative class of causatives at all: to make someone do something is equal to 'causing that someone does something' (141, cf. Siro 1978 and Hakulinen - Ojanen s.v). Accordingly, the question can be looked upon as one of the degree of abstraction that is aimed at. Comrie (1981: 159-160) classifies causatives into three classes: synthetic, analytic, and lexical or suppletive (kill - die). With the exception of the last-named type, this classification can be applied to Finnish curatives as well, whose distinctive characteristic is that the derivative is morphologically different from the basic verb notably by the derivative affix. In the analytic (phrasal) structure both the causing and the caused action/activity have each a predicate verb of their own. The lexical curative, where there is no morphological relationship between the causation and the action, is not known in Finnish. This is a feature that distinguishes the curative from the causative.

1.3. Kytömäki's corpus of well over three hundred curative derivatives is based on The Reverse Dictionary of Modern Standard Finnish, which for its part was compiled from the data in The Dictionary of Modern Standard Finnish (Nykysuomen sanakirja). Kytömäki very rightly emphasizes the specimen character of her lists, as the curative is a productive type of verbal derivation (1978: 146). The derivative affix of the curative is in its abstract basic form TTA. On the surface level it is of the shape -tta-, -ttä-, -ta- and -tä-(Kytömäki 1978: 137 n.).

As Kytömäki (142-143) points out, it is not always possible to tell without the support of the syntactic context whether a verb thus derived is a 
clear causative, a manifest curative, a borderline case, or something else, e.g.

(1) causative: Lämpö SULA-TTA-A lumen. 'The warmth makes the snow melt/melts the snow'.

(2) curative: Hän ETSI-TTI meillä kukkaroaan. 'She had/made us look for her purse'.

(3) context-dependent: Minua LAULA-TTA-A. 'Something makes me feel like singing' (causative).

Opettaja LAULA-TTA-A oppilaitaan. 'the teacher makes her pupils sing' (curative).

(4) problematic: elättää 'keep alive, feed' / imettää 'nurse, give the breast, breast-feed' etc.

To eliminate any doubt about the curativity of a derivative it is possible to attach an additional TTA element to a suffixed base, or the composite derivative element U-TTA, e.g. juotattaa 'to make s.o. drink', laulatuttaa 'to make, have s.o. sing (a song)'. Thus, the derivative affixes and their combinations for the curative are TTA/TTA-TTA and U-TTA/TTA-U-TTA (Kytömäki 1978: 148-149, cf. Vesikansa 1978: 112).

1.4. After such a disambiguating extra derivative step "the meaning (of the derived verb) may be the same as it was after the first step, with the difference that the curative character is now secured" (Kytömäki 1978: 147), thus uittaa laivaa 'to float a model ship' (the boat "floats along" on the pond etc.) vs. uitattaa laivaa lapsella 'have/make the child float his model ship'.

Vesikansa (1978: 112) quotes a few curative verbs derived by double affixes viz. haetuttaa 'to cause s.o. to make s.o. fetch', luetuttaa 'to cause s.o. to make s.o. read', lyötättää 'to cause s.o. to make s.o. stamp', teetättää 'to cause s.o. to have s.o. do' with the comment that the corresponding single-affixed derivatives haettaa 'to make s.o. fetch', luettaa, lyöttää and teettää are completely adequate and satisfactory. Similarly, he recommends the synthetic or morphological curative - on the grounds of efficiency - to be preferred to the analytic verb phrase. Thus tiivistyttää is better than antaa tiivistää, lyöttää better than antaa lyödä (cf. above 1.1.). This view, consistently held by The Dictionary of Modern Standard Finnish with regard 
to double and analytic curatives, derives from the general objective of the dictionary 'to comprise all the words used and accepted for use in present-day literary and educated standard' (Foreword p. 5). Thus, according to the Dictionary, s.v. antaa 4 "antaa jkn tehdä jtk" 'let, make s.o. do smth.' the 'factitive verb' teettää is the preferred alternative; in the same way, curatives of one derivative step are declared to be better than the corresponding double formations: teetättää 'to cause to have smth done', better: teettää 'to have smth done', or tuotattaa 'to cause smth to be brought', better tuottaa 'to have smth. brought'. Kytömäki (1978: 147) comments on the forms haettaa vs. haetuttaa that the double derivative element in the latter verb "does not change the meaning any further" - thus both contain "double curativity".

However, this needs some qualification. There are situations and conditions of the external world in which it is not a matter of indifference whether a curative of one or two derivative steps is used if it is our desire to focus on the relationship between the indirect and direct actants.

(a) Kapteeni haetti luutnantilla ratsunsa.

'The Captain had his horse fetched by the lieutenant'.

(b) Kapteeni haetutti luutnantilla ratsunsa.

'The Captain told (commanded, ordered) the lieutenant to have his horse fetched'.

In case (a) the captain's orders were to the effect that the lieutenant himself was to go for the steed, whereas in case (b) the junior officer was told to see to it that the captain's horse was brought to the house door, obviously by a dragoon or a groom. The analytic construction makes the difference explicit.

$\left(a_{1}\right)$ Kapteeni antoi luutnantin hakea ratsunsa.

'The Captain had the lieutenant fetch his horse'.

$\left(b_{1}\right)$ Kapteeni antoi luutnantin antaa hakea (= haettaa) ratsunsa (tallimiehellä).

'The Captain commanded the lieutenant to have the groom fetch his horse'.

In $\left(a_{1}\right)$ the lieutenant is the direct agent who carries out the command by going to the stables and fetching the captain's horse, but in $\left(b_{1}\right)$ in his role as the indirect agent he need not seize the bridle of the mount. The imme- 
diate or real agent is understood to be inherently present even if it is not concretely expressed (Kytömäki 1978: 142).

2.1. In Finnish it is possible to derive curative verbs also by three derivative steps: the form teetätyttää 'to make s.o. cause s.o. to have s.o. do smth', which contains a threefold derivative element, is characterized by Vesikansa as "a climax of having smth. done" and unacceptable in correct usage (1978: 112 and note). This is consistent with his reserve towards double curatives, referred to above. As The Dictionary of Modern Standard Finnish rejects threefold curatives as unacceptable and does not list them, it is obvious why Kytömäki's corpus does not contain such forms.

However, the idea of the present paper was suggested by a play on words from North-Eastern Finland, quoted by Prof. Alpo Räisänen. It goes as follows.

Hevonen vetää (tukkeja) The horse hauls (logs). Hevosmies veä-ttä-ä (tukkeja hevo- The driver makes the horse haul sella) logs. Työnjohtaja veä-tä-ttä-ä (tukkeja The foreman orders the driver to hevosmiehellä) get the logs hauled (by the horse). Tukkiyhtiö veä-tä-ty-ttä-ä (tukkeja The lumber company orders the työnjohtajalla) foreman to cause the driver to have the logs hauled (by the horse).

According to Räisänen this playfully linguistic analysis of the hierarchy at a lumbercamp is fully motivated by the fact that in the extralinguistic reality each derivative has a distinct referent (signifié, thing-meant) to activate the expressive potential of the language.

The above string of accumulative curative derivatives is not only an entertaining play on words, but it is interesting also from a linguistic point of view: the questions arise of whether it is an instance of recursive derivation and whether parallels to it are to be found in other languages.

2.2. Our play on words can be described by means of general symbols, thus.

$\begin{array}{lll}\text { Basic level } & X_{1} \text { tekee } Y: n . & X_{1} \text { does } Y . \\ \text { 1st step } & X_{2} \text { tee-TTÄ-ä } X_{1}: \text { llä } Y: n . & X_{2} \text { makes } X_{1} \text { do } Y . \\ \text { 2nd step } & X_{3} \text { tee-TA-TTA-ä } X_{2}: \text { lla } Y: n . & X_{3} \text { makes } X_{2} \text { do } Y . \\ \text { 3rd step } & X_{4} \text { tee-TA-TY-TTA-ä } X_{3} \text { :lla } Y: n . & X_{4} \text { gets } X_{3} \text { to make } X_{2} \\ & & \text { cause } X_{1} \text { to do } Y .\end{array}$




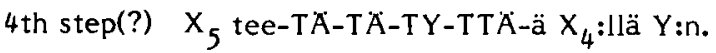

$X_{5}$ has $X_{4}$ get $X_{3}$ to make $X_{2}$ cause $X_{1}$ to do $Y$.

Vesikansa is of the opinion that in living idiom there is no need for such theoretical refinement as the third step would require (1978: $112 \mathrm{n}$.), which is why curatives of the third power do not occur in the spoken standard. Our quotation, however, goes back to the (informal) idiom at a lumber camp; Räisänen feels that curatives of three derivative steps are theoretically and morphologically quite possible in Finnish. It is another question that threefold curatives are rarely used, because there is little functional need for them in ordinary language (in a letter to the author). It is possible to derive one curative from another in the same way as a causative can be derived from a causative (cf. Comrie 1981: 160); the third derivative step, however, seems to be the limit beyond which the acceptability of the resulting derivative may appear questionable. Kytömäki's corpus is not arranged according to the basic form to which the derivative affixes are attached, because the material was compiled at random (Kytömäki 1978: 145). If a list arranged according to the base of derivation were at our disposal, it would be possible to search for the phonological, morphological, semantic and pragmatic constraints and restrictions that govern the number of the derivative steps.

2.3.1. It seems to me that the essential point in the description and explanation of the structure and behaviour of the curative verbs is the fact that the analysis of these derivatives is not only a question of a base and a derivative, but also one of two predications and the expression of their relationship by methods of syntax (cf. Siro 1978: 5). It is characteristic of curative causatives that two nominals with different (syntactic) roles are connected with them, viz. the initiator of the activity and the immediate actant or actor, each having only one place available. When the sentence resulting from the first derivative step $x_{2}$ tee-TTA-ä $x_{1}: l l a ̈$ Y:n is moved up into the next curative power, in the resulting sentence $X_{3}$ tee-TA-TTA-ä $X_{2}:$ lla $Y: n$ the iniator of the embedded sentence $\left(X_{2}\right)$ takes the role of the immediate actor (agent) at the same time as the previous direct agent $\left(X_{1}\right)$ is deleted, something that happens to $X_{3}$ and $X_{2}$ respectively when the next derivative step is carried out. As will be seen from figure 1 , the object of the activity (the "patient") retains its place throughout. 


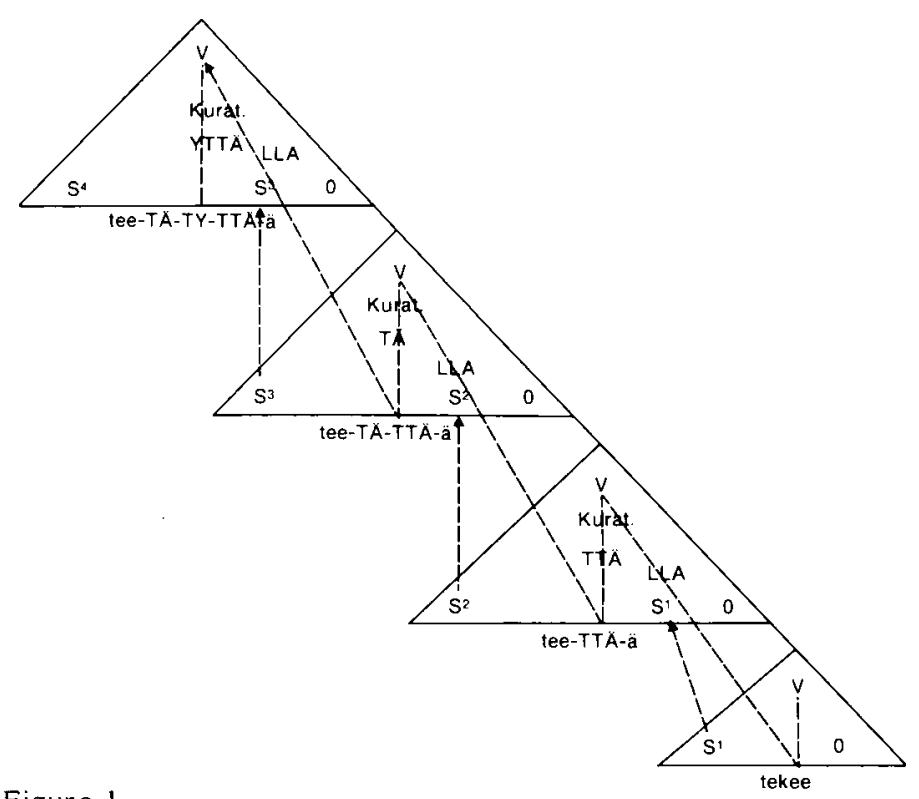

Figure 1.

2.3.2. The deletion of the direct agent (actor), $X_{1}$ and $x_{2}$ in the above example, seems to be an accepted fact of the usage, dictated by the stringency of syntactic space. The ensuing vagueness and/or ambiguity are compensated for by means of our knowledge of the extralinguistic world. This is a manifestation of the inherent imprecision of language, the fundamental role of which in all linguistic communication - ranging over a scale from word meanings to structure and phrases - is emphasized in literature from Wittgenstein (Tractatus 4.002) to present-day scholars (e.g. Quirk 1969: 65, 208).

The main objective in using a deverbal derivative, the curative that is, is to express that an activity/action is caused to be carried out by someone else than the subject of the curative sentence. Thus, it is not essential except in special cases - to give prominence to the subordinate relationship between the initiator or the original source of the action and the partici- 
pating actants down to the direct agent, who carries out what is "being had done", by means of repeated application of the derivative procedure.

There seems to be in present-day Finnish a tendency to get along with curatives of one derivative step, but, if need be, curativity can be substantiated by means of one additional derivative step. The unspecific nature and marginal role of the curative component of such derivatives is aptly illustrated by the following sentence.

Tätini möi huoneistonsa ja rake nsi omakotitalon liitosalueelle.

My aunt sold her flat and bu il t a cottage in the suburban area. The form rakensi ('built') is immediately interpreted as a curative (= rakennutti 'had... built'), which would also be the case with a corresponding expression with a masculine subject (e.g. my uncle, $\mathrm{Mr}$ N. etc.), even if the person in question had the necessary know-how and physical strength for putting up a house. Should the person denoted by the subject really erect the house with his own hands, it would be indicated by means of an apposite additional complement, such as itse 'himself', omin käsin 'with his own hands' etc. ${ }^{2}$

If the sequence of synthetic curatives (above in 2.2) is de-synthesized into a string of analytic ones, the result is unambiguous and explicit, and the redundant reiteration of the object $(Y)$ is eliminated, thus:

$X_{4}$ antaa $X_{3}$ :n antaa $X_{2}$ :n antaa $X_{1}$ :n tehdä $Y$ (see above 2.2.). Both the iniator and all indirect agents as well as the object (patient) find now expression. True, the explicitness is bought at the price of inelegant repetition of the same construction, something that can continue without limit. In synthetic curatives the iteration is effected by means of the derivative element up to three, eventually four steps.

3.1. As it is possible, both in theory and practice, to derive multiple curatives in Finnish by attaching an additional derivative affix to a 'base' that has one or two such elements, how far, then is it legitimate to look upon this phenomenon as an instance of recursive derivation?

A rule is said to be recursive, if it is "capable of repeated application in generating a sentence..." (Crystal 1980: s.v.) (cf. Lyons 1969: 222 and Hakulinen - Ojanen 1978: s.v., where rules or structures that can be repeated an indefinite number of times are defined as recursive). The term 'rule' needs some specification before it is possible to decide whether and in what sense 
recursiveness can be spoken about in word-formation in general and in derivation in particular.

3.1.1. In syntax, which the concept of recursiveness derives its origin from, "the unlimited repetition of the same rule means the repetition of the same operation, e.g. co-ordination, relativisation, complementation (embedding, see Crystal 1980: s.v.) \&c. ad infinitum, which also applies to various structures, such as modification of nouns with adjectives or prepositional phrases. In this sense the analytic ("overtly causative" Lyons 1969: 387) curative is indefinitely recursive $\left(X_{1}\right.$ causes $X_{2}$ to.... have $X_{n}$ do $Y$ ).

3.1.2. In word-formation, the category of compounding admits of description as recursive, the repeated operation being co-ordination and/or subordination, e.g. pienoiskeittiökalusteosasto 'mini-kitchen furniture department', cf. a railway station refreshment room furniture superintendent and German Donaudampfschiffahrtsgesellschatskapitänsanwärteruniform, and Stein's comments on these two examples from the viewpoint of lexical and syntactic compounds (1977: 224ff, see also Bauer 1983: 67-71).

Derivation is an affixal operation affecting both the word class and the lexical (semantic) class membership of the base. Once a verb has been derived from a noun, which has thus been transferred from word class "noun" to word class "verb", the derivative process is completed: mustata 'to blacken' leaves no need for a form with double suffix *mustatata '*blackenen'. It is on the basis of this type of reasoning that Stein excludes recursiveness from the field of derivation (1977: 219-236).

Recursiveness in a narrow interpretation, i.e. repeated application of the same derivative process (e.g. nominalisation) by means of the linguistic means (e.g. a given nominal suffix), is not to be identified with multiple suffixation. Thus, the reflexive verb levittelehtiä 'to tend to spread out oneself from time to time', which according to Hakulinen (1941: 247, 1961: 186 \& 1968: 226) contains no less than five derivative elements with momentaneous and frequentative connotations, does not conform to the criteria of recursiveness as we see them.

In fact, Hakulinen regards such accumulation of derivative matériel as "an attempt to express primitively pedantic shades of meaning simultaneously". Cf. Engl. unaffectedness, German Furchtlosigkeit 'fearlessness', Sw. oförsiktighet 'incautiousness'. 
True, there are instances of occasional multiple application of certain qualificative (modifying) affixes, e.g. repetition of the diminutive suffix in Finn. lapsukainen 'dear little child', German Kindleinchen (Plank 1981: 128), or It. donnettina (Stein 1977: 225), or double feminine suffixes to mark the feminine counterpart to masculine nouns (German 'Movierung'), such as German Baronessin, Diakonissin, Prinzessin (see Paul 1920: 163 \& Plank 1981: 76), cf. a 31-year-old girl bachelorette (Time Magazine 1980 Nr 51: 13b). However, these formations are to be looked upon as due to stylistic freedom or to re-analysis and lexicalisation. Plank (l.c.) quotes one instance of double application of the same prefix, viz. un-unabhängig "un-in-dependent", which in his opinion is just acceptable and has an ironic nuance (connotation). ${ }^{3}$

An interesting borderline case between compounding and multiple prefixation are such German formations as Ur-(ur-ur-)...grossmutter/-enkel/-vater or vor-vor-...gestern, über-über-...morgen. They compare with Finn. isoiso-...isänisä/-äidinäiti, pojan-pojan-... pojan-poika or Sw. farfarsfarfarsfarfar and it seems that formations like pre-pre-Raphaelite or post-post-war or re-re-arrange would be acceptable in English, cf. Bauer 1983: 67.

Although it is a matter of doubt whether any of the above formations can be accepted as instances of recursive derivation (the kinship terms and adverbs of time seem to belong to compouding), they have a bearing on our main problem, the eventual recursiveness of the Finnish curative verbs: in all the quoted items the word-formative procedure changes not the word class of the base, but rather its lexical (semantic) class. And what is more important, the recursiveness which is realized by iterative compounding touches a modifying parameter of the base, not its nuclear meaning, that is to say, in the above cases its position on a cline or continuum, where the distance between each step is one generation or 24 hours of a day.

3.2. In Finnish there are different types of deverbal verbs; Erkki Itkonen (1966: 247) mentions the frequentative, continuative, momentaneous, causative and curative verbs (cf. verba intensiva, frequentativa and desiderativa in Latin). Causative and curative verbs differ from the rest in that the derivative process affecting the quality of the action (German $A k-$ tionsart) expressed by the basic verb can be repeated: it is not possible nor meaningful to derive another frequentative from such a verb, just as a mo- 
mentaneous derivative cannot yield a secondary momentaneous verb, e.g. nukahtaa 'fall asleep' ( $\leftarrow$ nukkua 'sleep') excludes repeated derivation for the natural reason that falling asleep is possible only once at a time. But a frequentative derivative is fully acceptable, viz. nukahdella 'to keep dozing of $f^{\prime}$.

But, as was stated above, it is possible to derive a curative from a curative and repeat this procedure without affecting the activity itself that the basic verb denotes. The haulage of the logs in the lumber camp example remains the same struggle between the horse and the load independent of who is the initiator - the company, the foreman or the driver (horseman).

Thus, the curative derivation in Finnish, which can be carried on to the third, occasionally even four th power, is in full agreement with our interpretation of recursiveness, as the operation makes use of the same derivative element, TTA in its abstract form (see above 1.3.), and each derivative step removes the initiatior of the activity by one step further away. The curative, in the same way as the causative is of peculiar character. It has its given place in the Finnish verb paradigm in its capacity as a kind of mood or aspect but on the other hand it is a derivative, not a flexional form, and accordingly belongs to word-formation as well. The recursiveness of a curative is invested in the aspectual or 'modal' component; the unlimited recursiveness of the analytic curative is conclusive evidence of the recursive character of the curative. Even if the derivative component of a synthetic curative blocks the recursive derivation after three or four steps at a maximum, there is the analytic construction to carry the process to any length according to the needs of communication.

The description and analysis of the morpho(phono)logical, semantic, syntactic and pragmatic factors that block the curative derivation requires a special study. In the present connection reference can barely be made to the insufficiency of the syntactic means of expression, the tendency of the language to avoid the iteration of phonetically identical derivative elements, and the needs of normal communication, which do not require highly specified expression of the details of action.

4.1. Vesikansa declares (1978: 113) that "foreign" (i.e. other than Finnish) languages lack a special type of curative verb, which is why they have to take recourse to a syntactic phrase (analytic construction) to express 
curativity. In a very general sense this may be so, but not without some qualification. Let us first adduce a few examples from different (European) languages.

English

(la) Henry made (had) Tom write the letter.

(1b) Henry got Tom to write the letter.

(1c) Henry had the letter written by Tom.

German

(2) Heinrich liess Thomas den Brief schreiben.

French

(3) Henri a fait écrire la lettre par Thomas.

Italian

(4) Enrico a fatto scrivere la lettera par Tommaso.

Cf. Lyons 1969: 386-387, Siro 1978: 42 and passim, Comrie 1981: 161-164 and Coopmans 1983: 455-474 with critical comments on Comrie's analysis of the analytic causative.

4.2. In a language that has no synthetic curative, such as Swedish, also as it is spoken in Finland (as the second national language), the need for such convenient derivative may be realized in a hybrid formation I have come across in informal speech, viz. *skratatta - skratta 'to laugh' + TTA, the Finnish curative derivative element 'to make s.o. laugh'.4

In Turkish, which is an Altaic language, there is a multiple curativecausative derivation, which has come to be linguists' favourite example of recursive derivation, cf. Lyons 1969: 352, Plank 1981: 127 \& Comrie 1974 and 1981: 158-.

öl-mek 'to die' öl-dür-mek 'to kill, make die' öl-dür-t-mek 'to cause s.o. to kill s.o.' öl-dür-t-tür-mek 'to have s.o. cause s.o. to kill smb.' öl-dür-t-tür-t-mek 'to have s.o. make s.o. cause s.o. to kill 5.o.'

In the above sequence the first derivative step yields a causative, the following ones curatives the initiator of the act of killing being moved further and further away, from henchman to henchman. Comrie (1981: 160) is, however, right in assuming that "there is probably no language that illustrates the pure prototypical causative, with unrestricted iterativity of the relevant morphological process".

4.3.1. Among the Finno-Ugric languages Cheremis comes nearest to Finnish as regards the curative derivation: it has curatives of one and two derivative steps, the most frequent derivative element being $k t A$ which is cog- 
nate with the TTA of Finnish (cf. Hakulinen 1961: 188 and 1968: 228). A few examples:

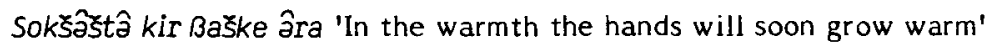
Kex̌at ‘̂alamak ârâkten ok kert 'Even the sun cannot warm everything' (= make everything grow warm)

Tư kußažlan ßüđâm ârâktâkten 'He had his old woman warm some water' (= make some water become warm)

In the same way, uryaš 'to sew' uryâktaš 'to have sewn' uryâktâktaš

'cause to have smth sewn'

âstaక̌ 'do, make' âstâktås 'have smth done' âstôktâktaక̌ 'cause to have smth made, done'

(Galkin IstoriCeskaja grammatika marijskogo jazyka. Morfologija Cast' II. Joškar-Ola 1966: 109-110).

4.3.2. A few sporadic examples of curatives of one derivative step have been found in some other Finno-Ugric languages, but they have not been systematically recorded for the obvious reason that they are not much used in normal communication. As Alhoniemi points out, only a versatile native fieldworker, who has a special interest in curative-causatives, can be expected to elicit these forms. Here are a couple of random instances.

Mordvian (Ersä dialect) tejevtems 'teettää' — t'ejems 'tehdä' (do, make); the stem of the curative tejevt is identical with that of the Finn. teettäa, the ms element being the termination of the infinitive.

Cf. Ziryanian gizedni 'kirjoituttaa' (to cause smth to be written) gizni; in these forms $-n i$ marks the infinitive.

In Vepsian, too, a synthetic curative can be formed (Zajceva 1978: $25 \mathrm{f}$. \& 53f.); the following examples were pointed out to me by Eugene Holman, M.A., of the University of Helsinki.

silinta 'to stand' $\rightarrow$ silžzutada 'make s.o. stand' $\rightarrow$ silžnutoitta 'have s.o. make s.o. stand' (cf. Finn. seisoa $\rightarrow$ seisottaa $\rightarrow$ seisotuttaa).

t'egetoitta sapkad 'to have boots made' (Finn. teettää saappaat)

Hambhan kibištab, mända vedatoitta 'When your teeth ache, go and have (them) extracted' (cf. Finn. vedättää).

4.3.3. Within the Finno-Ugric family of languages Hungarian, too, uses synthetic curatives of one or two derivative steps, but there are no in- 
stances of curatives of the third power (see Hetzron 1976: 381), (which does not necessarily mean that after the second step the recursion is absolutely blocked). Examples:

ég (intr.) 'to burn' $\rightarrow$ éget 'to cause to burn' $\rightarrow$ égettet 'to have s.o. cause to burn' (Finn. palaa - polttaa - poltattaa)

ir 'write' $\rightarrow$ irat 'to cause s.o. to write' $\rightarrow$ Írattat 'to have s.o. cause s.o. to write' (cf. Finn. kirjoittaa - kirjoituttaa - kirjoitututtaa)

sétál 'to walk, to have a walk' $\rightarrow$ sétáltat 'to make s.o. (take a) walk' $\rightarrow$ sétáltatat 'to cause s.o. to make s.o. walk', 'to cause s.o. to make s.o. take smb for a walk' (Finn. kävellä $\rightarrow$ kävelyttää $\rightarrow$ kävelytyttää)

But according to the dictionary, curatives of one derivative step can in Hungarian be given the meaning of double ones, e.g. hord 'carry' $\rightarrow$ hordat 'to have smth carried, to cause s.o. to have smth. carried' (Finn. kantaa $\rightarrow$ kannattaa $\rightarrow$ kannatuttaa), hoz 'to bring' $\rightarrow$ hozat 'to have s.o. bring smth, to cause s.o. to have s.o. bring smth.' (Finn. tuoda $\rightarrow$ tuottaa $\rightarrow$ tuotattaa), or tesz 'do' $\rightarrow$ tétet 'have s.o. do smth, to cause s.o. to have s.o. do smth.'

Hetzron's article does not provide any information about the possibility of the occurrence of causatives of the third power during early periods of Hungarian, but he refers to such formations in Awng and Kuušian languages. On the other hand, the blocking of the curative derivation after the second step as well as the possibility of using curatives of the first power as if they were forms of double curativity can be interpreted as indications of a morphologically regressive tendency of the curative. The role of pragmatics ("knowledge of the world") increases correspondingly.

4.3.4. In Estonian, contrary to expectation, there is no synthetic curative: that something is caused to be done or to happen is expressed by means of a syntactic phrase made up of the verb lasta (- *laskedak) 'to get s.o. to do smth, smth to be done' and the infinitive, thus: ma lasen ( $\leftarrow$ *lasken)parandada 'I have smth. repaired', Ma lasen avada, ...teha 'I have smth opened, done or made'. The construction lasta + infinitive resembles the corresponding German structure, e.g. tun lassen. The question to which there is no answer so far is this: has there ever been a curative derivation of even one step in present-day or early Estonian or in its dialects, and if the answer is in the negative, has the causative of Modern Estonian (which bears a slight though deceiving resemblance to the Finnish curative) been used in the cu- 
rative function, cf. kolkuta 'to hang, swing' $\rightarrow$ kolkutada 'to dangle, wave', rớmustuda 'to be glad, rejoice' $\rightarrow$ ró delay' $\rightarrow$ viivitada 'detain, keep up'. This whole set of questions requires an extended comparative study of the languages that are close relatives of Finnish, with due regard to diachronic aspects as well.

4.4.1. The remarkable recursiveness of the curative-causative derivation in Turkish compares interestingly with the productivity of the curative in Finnish and related languages. The question suggests itself whether the synthetic curative is a characteristic of both Altaic and Uralic languages or whether the neighbourhood of these language families in the far distant past has provided possibilities for borrowing in either direction.

4.4.2. Another related question is the import of the tendency to prefer curatives of one or at a maximum two derivative steps to threefold forms, or to use the unaffixed verb ("zero-curative") in this function (cf. above 2.3.2.). To manage with minimal morphological means is the recommendation of The Dictionary of Modern Standard Finnish. Curatives of three derivative steps come near the acceptability limit in the sense that they are very seldom used, even if they are theoretically possible. In Hungarian the same trend can be observed, there being no evidence of curatives of the third power, and in Estonian there is no morphological curative at all (typically enough, curativity can be expressed by means of "zero" curative", e.g. Ma kavatsen müüda mun korter vanalinnas ja ma ehit an individuaalelamu eeslinnas 'I will sell my flat in town and build a house in the suburban area').

Taken together, these instances indicate a shift of functional load from morphological elements to the knowledge of the extralinguistic world, a feature shared by Finnish and related languages. Our internalized syntax does not recognize any pronounced need for topicalizing a structural hierarchy of curative derivations and constructions.

4.5. The derivative elements of the curative in Finnish (-TTA-), Cheremis (-KT-) and Hungarian (-TE- - $-\mathrm{HT}_{-}$) are believed to go back to a verb denoting 'doing', which in the early periods of the languages was used to form an analytic, 'periphrastic' curative (Hetzron 1976: 376-381 and above 4.3.1.).

If this is correct, the present-day curative of one to three derivative steps is anything but a remnant of a primitive, probably more fully marked 
recursive derivative; on the contrary it would rather seem to be a secondary synthetic formation that goes back to an analytic basic construction. Moreover, the curative displays indications of being reduced morphologically, as was shown in 4.4.2.

Jespersen is one of those linguists and philosophers of language who saw progress in language only in a development from synthetic toward analytic structure. Consequently he declared that analytic languages are a priori superior to the rest, but his evidence was restricted to Indo-European and Semitic languages only. The growth (emergence) of a synthetic curative in addition to an analytic one admits of a different assessment, for it can be looked upon as an enrichment and expansion of the expressive potential of the language. At the same time it is a step in the direction of economy of expression, which is one of the truly universal laws of language (see Hakulinen 1961: 67 and 1968: 84-85, Ravila 1961: 81-83, Itkonen 1966: 332-340, Joki 1966: 15-22 \& Raun 1963: 58-65).

4.6. Above I have tentatively outlined the general course of the development of the curative - mainly in some Finno-Ugric languages - from a primitive analytic construction to a synthetic derivative of varied recursiveness, the current use of which displays a tendency to minimize synthetic derivative elements (syntheticity), even down to zero, at the same time as context and knowledge of the extra-linguistic world (pragmatics) are given increasing communicative importance.

This suggests the question of how far the curative derivation is involved in a cyclic development: from original analyticity to full syntheticity, which seems to be on its way back toward analyticity over reduced synthetic forms. True, cyclic development in the proper sense of the term, is in the first place connected with syntax and flexion (cf. Vennemann 1973: 25 and Hiltunen 1983: 23). But cyclic development is - mutatis mutandis - conceivable also in word-formation: in the same way as the fixed word order of an analytic language diminishes the need for lexical and functional markers of the words constituting a sentence, context and knowledge of the world, the prime parameters of the curative, may well achieve the same effect, cf. denominal conversion verbs and deverbal conversion nominals in English. It goes without saying that this is a set of problems that requires extensive 
comparative diachronic research; besides, synchronic studies should be extended to dialects both in Finnish and related languages.

5.1. It seems legitimate to sum up the above considerations as follows:

- The curative-causative derivation is an organic feature of Finno-Ugric languages, but its productivity in Modern Turkish is an indication of its existence in Altaic languages as well.

- In Finnish curative derivatives are possible (and acceptable) up to the third (?even fourth) derivative step, and satisfy the criteria of recursiveness.

- As regards the possibility of curatives of two or three derivative steps in languages related to Finnish, no coherent picture is possible at the present stage, because the word-formation and derivation in particular in these cognate languages has so far been insufficiently ("imperfectly and poorly", Alhoniemi in a letter to the author) researched.

- Curativity can also be expressed in these languages analytically, in which case the relevant rule is indefinitely recursive. In fact, the analytic construction seems to be "universal" in the sense that it is independent of the typological class of the language in question.

5.2. The study of curative derivatives and constructions is, as Comrie (1981: 158) observes about causatives, of topical interest and importance not only in an interdisciplinary but also a linguistic sense, not least in regard to language-specific, universal, and typological aspects.

From the viewpoint of word-formation, which is the present author's prime interest, the peculiar character of the curative in the no-man's-land between derivation and flexion with its morphological, semantic and syntactic features and implications is a challenging motivation for a reconsideration of the current models of WF, with particular emphasis on the role of syntactic and extralinguistic context. Wittgenstein wrote, "Names have meaning only in context" (Tractatus 3.3.) and it is the context that regulates the lexical role, the derivative category, as well as the need for morphological markers of a derivation. 


\section{NOTES}

1 The Swedish translation of the quoted lines reads "Jag har teatertruppen spela nånting likt min faders mord inför min farbror". Cf. the corresponding Finnish lines "Tahdon, että he esittävät jotakin isäni kuoleman tapaista setäni edessä".

2 I owe this idea to Dr. Tapani Lehtinen. For that matter, the English sentence, too, is understood as a curative.

${ }^{3}$ A quality or characteristic of a basic adjective cannot be intensified or toned down by repetitive application of the derivative element. Thus *typerä-hkö-hkö 'more or less stupid' or *kell-ahtava-htava 'of sligtly yellowish hue' are definitely unacceptable, whereas kellahtavahko 'sligtly yellowish' is current (see Koski 1983: 304-305). Another type of derivative process by means of the "same" derivative element that suggests itself in this connection is what could be called secondary conversion, e.g. smoke sb. $\rightarrow$ smoke $v$. (a cigarette) $\rightarrow$ smoke sb. 'an act of smoking', but this question cannot be discussed in this connection.

4 Another example of such sporadic morphological borrowing is the use of the Finn. myydä 'to sell' as a medio-passive, in the same way as Engl. The book sells well 'Kirja myy hyvin'. So far, I have not come across any other examples of Finnish transitive verbs thus used.

${ }^{5}$ For these as well as the examples from Estonian I am indebted to Professor Antti Sovijärvi.

\section{REFERENCES}

Bauer, Laurie (1983) English Word-Formation. Cambridge University Press.

Comrie, Bernard (1975) "Causative and Universal Grammar" Transactions of the Philological Society 1974: 1-32. Oxford.

Comrie, Bernard (1981) Language Universals and Linguistic Typology. Cambridge.

Crystal, David (1980) A First Dictionary of Linguistics and Phonetics. London.

Hakulinen Auli \& Ojanen, Jussi (1976) Kielitieteen ja fonetiikan termistöä. 2. painos. Suomalaisen Kirjallisuuden Seuran toimituksia 324.

Hakulinen, Lauri (1961) The Structure and Development of the Finnish Language. Indiana University Publications. Volume 3 of the Uralic and Altaic Series. Bloomington.

Hakulinen, Lauri (1968) Suomen kielen rakenne ja kehitys. Helsinki. 
Hetzron (1976) "On the Hungarian Causative Verb and its Syntax". Shibatani: $371-98$.

Hiltunen, Risto (1983) The Decline of the Prefixes and the Beginnings of the English Phrasal Verb. Annales Universitatis Turkuensis Ser. B Tom. 160.

Itkonen, Erkki (1966) Kieli ja sen tutkimus. Helsinki.

Joki, Aulis J. (1966) Maailman kielet. Tietolipas 75. Helsinki.

Koski, Mauno (1978) "Suomen sananjohdon perustyypit" Suomen Kielitieteellisen Yhdistyksen julkaisuja 2: 103-117. Turku.

Koski, Mauno (1983) Värien nimitykset suomessa ja lähisukukielissä. Suomalaisen Kirjallisuuden Seuran toimituksia 391.

Kytömäki, Leena (1978) "Kuratiivikausatiivit." Rakenteita 129-150.

Lyons, John (1969) Introduction to Theoretical Linguistics. Cambridge.

Paul, Hermann (1920) Prinzipien der Sprachgeschichte. 5. Aufl. Halle.

Plank, Frans (1981) Morphologische (Ir-)Regularitäten. Studien zur deutschen Grammatik 13. Tübingen.

Raun, Alo (1963) Johdatusta Strukturaalikielitieteeseen. Tietolipas 30. Helsinki.

Ravila, Paavo (1961) Johdatus kielihistoriaan. Tietolipas 3. Helsinki.

Quirk, Randolph (1969) The Use of English. 2nd ed. Bungay.

Shibatani, Mashayoshi (1976) ed. "The Grammar of Causative Constructions." Syntax and Semantics vol. 6.

Siro, Paavo (1975) Sijakielioppi. Helsinki.

Siro, Paavo (1978) Kausatiivien kielioppia. Turun yliopiston suomen kielen laitos.

Stein, Gabriele (1977) "The Place of word-formation in linguistic description" Brekle-Kastovsky Perspektiven der Wortbildungsforschung. Beiträge zum Wuppertaler Wortbildungskolloquium vom 9.-10. Juli 1977: 219235. Bonn.

Vennemann, Theo (1973) "Explanation in Syntax". Syntax and Semantics vol. 2.

Vesikansa, Jouko (1978) Johdokset. Sananjalka.

Zajceva, M. I. \& Mullonen M. I. (1972) Slovar vepsskogo jazyka. "Nauka" Leningrad. 
Zajceva, M. I. (1978) Suffiksalnoe glagolnoe slovoobrazovanie v vepsskom jazyke. "Nauka" Leningrad.

Zimmer, Karl E. (1976) "Some Constraints on Turkish Causativization". Shiba$\operatorname{tani} 399-412$. 